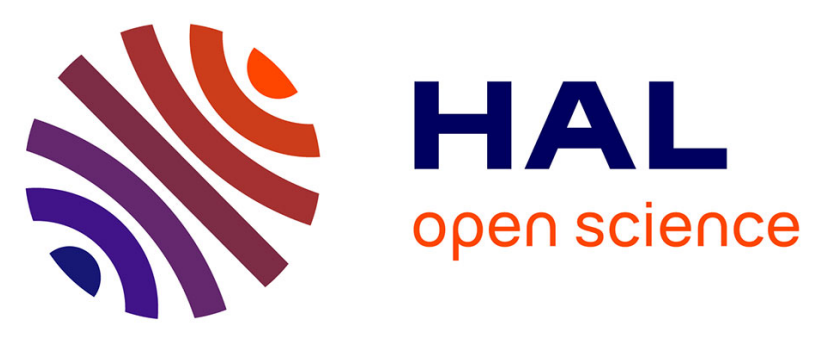

\title{
RELATION BETWEEN MORPHOLOGY AND DIETARY TRAITS IN HORSE JUGAL UPPER TEETH DURING THE MIDDLE PLEISTOCENE IN SOUTHERN FRANCE
}

\author{
A. Uzunidis, Florent Rivals, Jean-Philip Brugal
}

\section{To cite this version:}

A. Uzunidis, Florent Rivals, Jean-Philip Brugal. RELATION BETWEEN MORPHOLOGY AND DIETARY TRAITS IN HORSE JUGAL UPPER TEETH DURING THE MIDDLE PLEISTOCENE IN SOUTHERN FRANCE. Bulletin de l'Association française pour l'étude du quaternaire, 2017. hal-01653327

\section{HAL Id: hal-01653327 \\ https://hal.science/hal-01653327}

Submitted on 1 Dec 2017

HAL is a multi-disciplinary open access archive for the deposit and dissemination of scientific research documents, whether they are published or not. The documents may come from teaching and research institutions in France or abroad, or from public or private research centers.
L'archive ouverte pluridisciplinaire HAL, est destinée au dépôt et à la diffusion de documents scientifiques de niveau recherche, publiés ou non, émanant des établissements d'enseignement et de recherche français ou étrangers, des laboratoires publics ou privés. 


\title{
RELATION BETWEEN MORPHOLOGY AND DIETARY TRAITS IN HORSE JUGAL UPPER TEETH DURING THE MIDDLE PLEISTOCENE IN SOUTHERN FRANCE
}

\author{
Antigone UZUNIDIS ${ }^{1}$, Florent RIVALS ${ }^{2,3,4}$, Jean-Philip BRUGAL ${ }^{1}$
}

\begin{abstract}
The morphometric adaptations and the phyletic evolution of the Equus genus during the Quaternary are still the focus of many studies. Several forms (species/subspecies) of Middle and Upper Pleistocene horses have been described in Europe but their spatio-temporal variations, in relation to the environment and the climate require further clarification. This is the case in particular for a typical Middle Pleistocene form: Equus mosbachensis ssp. In this paper, we present combined morphological and ecometric observations based on the upper teeth from three subspecies of this form from five sites: Camps-de-Peyre (E. m. campdepeyri), La Micoque (E. m. micoquii), Lunel-Viel I and Lunel-Viel IV (Equus m. palustris) and Igue des Rameaux (E. mosbachensis ssp.). The understanding of the specific characteristics of this taxon should enable us to better define the occupied habitat and environment This preliminary study shows the importance of the adaptive capacities of Equus mosbachensis and the pertinence of combined paleontological and ecometric studies for enhancing our understanding of the ecology and the evolution of fossil ungulates. In addition, some authors have postulated that the length of the protocone is correlated to a diet with a high grass content. Although this tendency may have existed during the Quaternary, our study shows, on a smaller chronological scale, that there is no correlation between this measurement and horse diet and paleoenvironment.
\end{abstract}

Key-words: Middle Pleistocene, Equidae, Diet, Mesowear, Microwear, Ecometry, Paleoenvironment

\section{RÉSUMÉ}

RELATIONS ENTRE LA MORPHOLOGIE DES DENTS JUGALES SUPÉRIEURES DES CHEVAUX ET LEUR ALIMENTATION DURANT LE PLÉISTOCENE MOYEN DANS LE SUD DE LA FRANCE

Les adaptations morphométriques et l'évolution phylétique du genre Equus au Quaternaire font encore l'objet de nombreux travaux. Durant le Pléistocène moyen et supérieur, plusieurs formes (espèces/sous-espèces) de chevaux ont été décrites en Europe mais leurs variations spatio-temporelles, en relation avec l'environnement et le climat, nécessitent d'être mieux définies. C'est en particulier le cas pour une forme typique du Pléistocène moyen : Equus mosbachensis spp., et nous proposons ici des observations combinées, morphologiques et écométriques, à partir des dents supérieures sur trois sous-espèces de cette forme et cinq gisements : Camps-de-Peyre (E. m. campdepeyri), La Micoque (E. m. micoquii), Lunel-Viel I et Lunel-Viel IV (Equus m. palustris) et l'Igue des Rameaux (E. mosbachensis ssp.). La compréhension des spécificités de ce taxon devrait permettre de mieux définir l'habitat occupé et l'environnement. Cette étude préliminaire illustre l'importance des facultés adaptatives d'Equus mosbachensis et l'intérêt de développer davantage d'études mêlant paléontologie et écométrie afin de mieux comprendre l'écologie et l'évolution des ongulés fossiles. Certains auteurs ont par ailleurs émis l'hypothèse que la longueur du protocône serait corrélée à une alimentation riche en graminées, s'il est possible que cette tendance existe à l'échelle du Quaternaire, à une plus petite échelle chronologique, notre étude montre qu'il n'existe pas de corrélation entre cette mesure et l'alimentation des chevaux et leur paléoenvironnement.

Mots-clés : Pléistocène moyen, Equidae, alimentation, méso-usure, micro-usure, écométrie, paléoenvironnement

\section{1 - INTRODUCTION}

Many studies with varied approaches focus on the dental and osteological adaptations of mammals to their environments (Janis, 1988; Köhler, 1993; Forsten, 1993; Cramer, 2002; Van Asperen, 2013). They aim to describe the morphometric characteristics in bones and teeth and to relate them to Quaternary habitats and climates, in order to gain a better understanding of the adaptive mechanisms of mammal species to their environment.

The Pleistocene is a geological period marked by alternating climatic phases and significant environmental changes from the Middle Pleistocene onwards, the extent and the rhythm of climatic cycles change radically and cold periods alternate more abruptly with temperate phases (de Beaulieu, et al., 2006).

\footnotetext{
${ }^{1}$ Aix Marseille Université, CNRS, Ministère de la Culture \& de la Communication, LAMPEA. Maison méditerranéenne des sciences de 1'Homme, 5 rue Château de 1'Horloge, FR-13090 AIX-EN-PROVENCE.E-mails: antigone.uzunidis@wanadoo.fr; brugal@mmsh.univ-aix.fr ${ }^{2}$ ICREA, Pg. Lluís Companys 23, ES-08010 BARCELONA. E-mail: florent.rivals@icrea.cat

${ }^{3}$ Institut Català de Paleoecologia Humana i Evolució Social (IPHES), Campus Sescelades URV (Edifici W3), ES-43007 TARRAGONA

${ }^{4}$ Area de Prehistoria, Universitat Rovira i Virgili (URV), Avinguda de Catalunya 35, ES-43002 TARRAGONA
} 
Like other taxa, equids adapted to these changes through morphometric variations of the skeleton and teeth: (1) large horses with massive bones were adapted to a mosaic-type environment dominated by steppes and scattered with thickets of trees; (2) very robust horses are correlated to a cold climate whereas more slender specimens were probably associated with a temperate oceanic climate (Van Asperen, 2010; Eisenmann, 1998).

However, the status of some of these adaptations - sporadic intra-specific variation or variation leading to real taxonomic differentiation - is still difficult to identify (Eisenmann, 1998, 2006). In this context, it is essential to link environmental parameters with different morphometric and ecometric criteria. Many forms are described without reaching consensus among researchers and consequently, the phylogeny of equids is still poorly known for the Pleistocene (Eisenmann, 1991; Forsten, 1999).

The literature on morphometric adaptations of equids to their environment is abundant. In particular, the upper teeth of horses are often studied in order to determine the role and the impact of food on their morphological and biometric characteristics. In this way, Gromova (1949) suggests that tooth length (mesio-distal diameter) varies according to the type of food. Eisenmann (1982) and Guadelli \& Prat (1995) propose a correlation between the length of the protocone of the upper teeth and a diet rich in abrasive plants, like those generally found in a steppe environment. Another example, which will not be discussed in this paper, concerns the importance of the folding of the enamel in the notches which could be correlated to a diet rich in abrasive plants (Gromova, 1949; Eisenmann \& David, 1990). However, these hypotheses have never been statistically tested. We propose a combination of ecometric studies (dental microwear and mesowear) and with classical quantitative (dimensional) studies in order to test these hypotheses and provide more information on the ecology of Quaternary horses.

\section{2 - MATERIAL AND METHODS}

Five Middle Pleistocene sites from the South of France have been selected. Selected sites from Southwest France are: Camps-de-Peyre, La Micoque, Igue des Rameaux (amont complex); Selected sites from Southeast France are: Lunel-Viel I and Lunel-Viel IV (fig. 1). These five localities were selected because of the availability of large sample of horse teeth, the good state of preservation of the remains, and the accurate knowledge of the chronological and ecological context at each site.

Camps-de-Peyre is a paleontological pit-fall located in the Lot-et-Garonne with no evidence of human presence. It has been dated to MIS 10 according to the large herbivorous fauna (Guadelli \& Prat, 1995). The horse remains come mainly from median strata and the deposits are suggesting several close events of accumulation (Guadelli \& Prat, 1995). The faunal assemblage, in particular the reindeer and rodents (Dicrostonyx

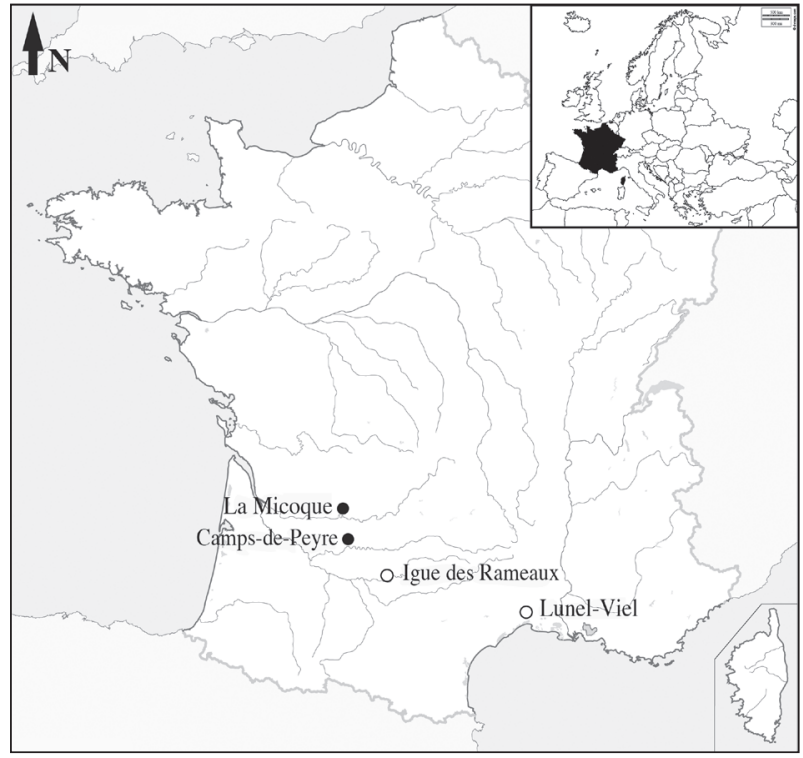

Fig. 1: Geographic location of La Micoque, Camps-de-Peyre, Igue des Rameaux and Lunel-Viel.

Fig. 1 : Localisation géographique de La Micoque, Camps-de-Peyre, l'Igue des Rameaux et Lunel-Viel.

torquatus, Microtus gregalis) suggest open areas under a cold climate (Guadelli \& Prat, 1995). The presence of Apodemus sylvaticus and Clethrionomys glareolus indicates small zones of trees around the site (Marquet, 1993).

La Micoque (Dordogne) is an archaeological site located at the base of a cliff which is dated to MIS 10 based on U-Series and ESR dating of teeth (Falguères et al., 1997). Humans were the only responsible for the accumulation of the bones remains and hunted horses almost exclusively. They represent $88.4 \%$ of the faunal association together with bovids (4.5\%), reindeer (3.9\%) and red deer (2.5\%) (Langlois, 2004). Deposits analysis show that climate was mainly cold and semi-arid (Texier \& Bertran, 1993). In this work only the richest layers, layers E, H and J, will be considered. Previous works have shown that the horse remains are very homogeneous and belong to the same species (Langlois, 2004; 2005).

Lunel-Viel is a complex of caves in South-East France (Hérault). In this study, we will analyse the rich fossil record recovered at Lunel-Viel I (in which deposits are separated in two complexes named "upper complex" and "lower complex") and Lunel-Viel IV. The two sites have been dated to MIS 9 according to the study of the large mammal fauna (Bonifay, 1980) and demonstrate a temperate climate under a humid environment (open zones with zone more bushy or forested areas). Hyenas are the main responsible for the bone accumulation with a diversified fauna and evidence of human presence is limited (Fosse, 1996).

The Igue (=pit-fall) des Rameaux is located in the South-West of France (Aveyron), with two locii (lower or "aval" and upper or "amont"). The "amont" zone is the richest and will be considered in this study. This zone is dominated by horse remains, with few bovid, cervid and carnivores, attributed to the end of the Middle Pleisto- 
cene (MIS 9) (Rouzaud et al., 1990). Human presence is very scarce and this accumulation is mostly natural, with individuals trapped in the pit-fall and with evidences of predation by carnivores (Coumont, 2006). The environment was probably more open under a cool-temperate according to faunal studies (Rouzaud et al., 1990).

However, the horses described in each of these five sites are morphologically similar and are attributed to the same species Equus mosbachensis, but with several subspecific differences: Equus m. micoquii at La Micoque (Langlois, 2005), Equus m. palustris at Lunel-Viel (Bonifay, 1980) and Equus m. campdepeyri at Camp-de-Peyre (Guadelli $\&$ Prat, 1995). Such diversity would represent a temporal and spatial differentiation of E. mosbachensis.

In order to define the diet of fossil horses in relation to their environment, we carried out an ecometric study based on dental mesowear and microwear analyses.

Dental mesowear (Fortelius \& Solounias, 2000; Kaiser \& Fortelius, 2003; Kaiser \& Solounias, 2003) outlines the type of food eaten by ungulate herbivores with selenodont or lophodont teeth by observing the shape and relief of the molar cusps. The information obtained summarizes the diet during the last months of the individual's life. Observations made on upper molars are coded from 0 to 6 , from the least abraded and the sharper cusps to the blunter cusps abraded by hard microelements contained in plants during chewing (Fortelius \& Solounias, 2000). Mihlbachler et al. (2011) applied an index, called the "mesowear score" (the measurement of the average degree of wear observed on the teeth in an assemblage), in order to facilitate the comparison of these observations between sites.

Dental microwear provides information about the diet during the last days of life of an individual. With the low magnification observation of dental enamel using a stereomicroscope, it is possible to quantify the microfeatures left by food and other ingested particles on the surface (Solounias \& Semprebon, 2002; Merceron et al., 2004; Rivals et al., 2009; Rivals et al., 2007a). Casts of the occlusal surface of teeth were observed using the protocol developed by Solounias \& Semprebon (2002) and Semprebon et al. (2004). The occlusal surface of each tooth was cleaned with acetone and $90 \%$ proof ethanol, then moulded with high-resolution silicone and reproduced with transparent epoxy resin. The casts were then observed with a stereomicroscope at magnification of $35 \mathrm{x}$. An ocular reticule was used to limit the observed zones to squares of $0.16 \mathrm{~mm}^{2}$. Different types of traces were identified and quantified using the terminology defined by Solounias \& Semprebon (2002) and Semprebon et al. (2004): scratches (elongated features), pits (small circular regular depressions), large pits (twice as large as pits), cross-scratches (scratches with a different orientation than most of the other scratches).

Scratches and pits were quantified on two zones of the paracone. This information was then compared to a database of extant ungulates (Solounias \& Semprebon, 2002) in order to classify a cohort of fossil ungulates in a given dietary group.
The combined application of dental microwear and mesowear analysis enables us to classify ungulates into four food categories:

- browsers: consumers of soft, not very abrasive plants (woody and non-woody dicotyledonous plants). Their teeth are characterized by high relief and pointed cups (low mesowear scores) and a microwear pattern with low numbers of scratches;

- grazers: consumers of very abrasive (rich in phytoliths) grasses (monocotyledonous plants). Their teeth are characterized by low relief and blunt cups (high mesowear scores) and a microwear pattern with high numbers of scratches;

- mixed-feeders: consumers of both types of plants in a non-selective way or with seasonal alternation. Their teeth show a combination of the groups described before;

- frugivores: fruit consumers.

The combined use of these methods provides information on dietary habits but also on the environment with possible information on the seasonality of the deposits. In our study, we only selected adult upper and lower teeth, excluding unworn teeth and the one from the very old individuals (Rivals et al., 2007b), and we preferentially sampled the second molars following the protocol established by Solounias \& Semprebon (2002). In this way, 56 teeth were studied from La Micoque (layer E: 22; layer H: 15; layer J: 19), 7 from Camps-de-Peyre, 35 from Lunel-Viel (cave I, upper complex: 13; cave I, lower complex: 14; cave IV: 8) and 31 from Igue des Rameaux (amont); giving a total of 129 teeth.

In addition, a more extensive morphometric study was carried out on all the upper teeth from the five sites in question, or a total of 309 teeth (tab. 1). Three occlusal measurements (DMD (=length), DVL (=width), length of the protocone) were systematically taken on each tooth (fig. 2). Only teeth from adult specimens were selected for this study.

Different statistical analyses are applied as part of this comparative study: the principal component analysis (PCA) and Kruskal-Wallis tests on small samples because of their robustness. The PCA is used to compare the morphometric data of the horse upper teeth from each site in order to evaluate their differences and determine which variable split or group the samples. Moreover we have added the microwear variable "scratches", as an illustrative data which does not interfere in the construction of the PCA. It will give us clues about the potential relation between diet and teeth morphometry. We used a Kruskal-Wallis test to verify if all the teeth from the layers/complexes/caves of the sites of La Micoque on one hand and Lunel-Viel on the other are different or if we can consider them as one entity or not for the subsequent tests and observations (i.e. homogeneity of data/collections). This test allows also to verify if the likely observed differences among the sites are significant. Lastly, we use the Spearman correlation test to compare the two sets of data i.e. tooth wear (diet) and biometric data (size).

In order to complete our understanding of the behavioral habits of $E$. mosbachensis we estimated the dura- 


\begin{tabular}{|c|ccccc|c|}
\hline Upper teeth & $\mathbf{P 2}$ & $\mathbf{P 3} / \mathbf{4}$ & $\mathbf{M 1} / \mathbf{2}$ & M3 & Total \\
\hline Rameaux (amont) & $\mathbf{2 5}$ & $\mathbf{4 4}$ & $\mathbf{5 6}$ & $\mathbf{2 4}$ & $\mathbf{1 4 9}$ \\
Camps de Peyre & $\mathbf{6}$ & $\mathbf{9}$ & $\mathbf{1 3}$ & $\mathbf{3}$ & $\mathbf{3 1}$ \\
Lunel Viel & $\mathbf{1 5}$ & $\mathbf{2 2}$ & $\mathbf{1 4}$ & $\mathbf{8}$ & $\mathbf{5 9}$ \\
\hline Lunel-Viel I upper complex & 6 & 13 & 4 & 3 & 26 \\
Lunel-Viel I lower complex & 5 & 8 & 10 & 4 & 27 \\
Lunel-Viel IV & 4 & 1 & 0 & 1 & 6 \\
\hline Micoque & $\mathbf{1 5}$ & $\mathbf{2 1}$ & $\mathbf{1 3}$ & $\mathbf{2 1}$ & $\mathbf{7 0}$ \\
\hline Micoque_layer $E$ & 6 & 4 & 3 & 8 & 21 \\
Micoque_layer $H$ & 1 & 4 & 2 & 4 & 11 \\
Micoque_layer $J$ & 8 & 13 & 8 & 9 & 38 \\
\hline Total & $\mathbf{6 1}$ & $\mathbf{9 6}$ & $\mathbf{9 6}$ & $\mathbf{5 6}$ & $\mathbf{3 0 9}$ \\
\hline
\end{tabular}

Tab. 1: List of the horse upper teeth from Camps de Peyre, Lunel-Viel, La Micoque and Igue des Rameaux (amont). Tab. 1 : Inventaire des dents supérieures des chevaux de Camps de Peyre, Lunel-Viel, La Micoque et les Rameaux (amont).

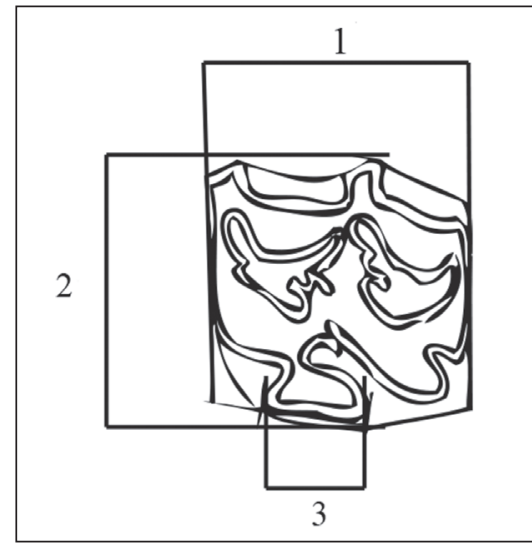

Fig. 2: Protocol of the measurements of horse upper teeth.

Measurement 1: mesio-distal diameter. Measurement 2: vestibulolingual diameter. Measurement 3: mesio-distal diameter of the protocone.

Fig. 2 : Protocole des mesures des dents supérieures de chevaux. Mesure 1 : diamètre mésio-distal. Mesure 2 : diamètre vestibulolingual. Mesure 3 : diamètre mésio-distal du protocône.

tion of accumulation of ungulates in the sites based on dental microwear. The duration of accumulation and seasonality factors are important criterion to consider. Dental microwear could bring some elements about this issue. Rivals et al. (2015) established a Bayesian statistical model based on extant ungulates to discriminate accumulations into three groups depending on the duration of formation of these accumulations: A) accumulations lasting for one season or less, B) accumulations over several contiguous seasons and C) sporadic events throughout time during different non-contiguous seasons. The data collected from the fossils are distributed among these three groups based on the standard deviation and the coefficient of variation of the numbers of scratches quantified on tooth enamel. The period of year (seasonality) is a crucial factor and has repercussion on type of eaten plants and habitats which need to be evaluated to better understand the eco-ethology of the horses and relation between diet and upper teeth morphometry.

\section{3 - MORPHOMETRIC DIFFERENCES}

The upper teeth are described by analysing the main component using three occlusal measurements [fig. 2: mesio-distal length (DMD), vestibule-lingual width (DVL), length of the protocone (P)], as well as the number of scratches. This factor contrasts moderately with the length of the protocone on the circle of the contributions of the variables in the top right of figure 3 , where it is illustrated for information only.

The different archaeological units are distributed into two groups in the factorial space. The centroid of La Micoque and Lunel-Viel levels on one hand, and Igue des Rameaux and Camps-de-Peyre levels on the other are opposite each other on axis 1 (49.75\% of variance explained by the PCA), mainly constructed around the contrast between the DMD and the length of the protocone. Axis 2 (35.6\% of variance explained by the PCA), based on the DVL variable, shows that the horses from Igue des Rameaux and Camps-de-Peyre have wider teeth than the horses from La Micoque and Lunel Viel.

The teeth from the layers/complexes from La Micoque (layers H, E and J) and Lunel-Viel (cave I, lower and upper complexes and cave IV) are biometrically very similar. This homogeneity of the upper teeth is confirmed by the Kruskal-Wallis test. This test did not indicate any significant differences between the teeth of the different layers from Lunel-Viel on one hand and La Micoque in the other. Thus, for the further parts of our analysis, we will consider the different Lunel-Viel complexes as a single statistical sample and the different layers of La Micoque as another single statistical sample.

The Kruskal-Wallis test on five upper tooth series confirms the presence of two metric groups identified by PCA: Lunel-Viel and La Micoque are characterized by shorter protocones than Camps-de-Peyre and Igue des Rameaux (amont) (tab. 2). These metric differences do 


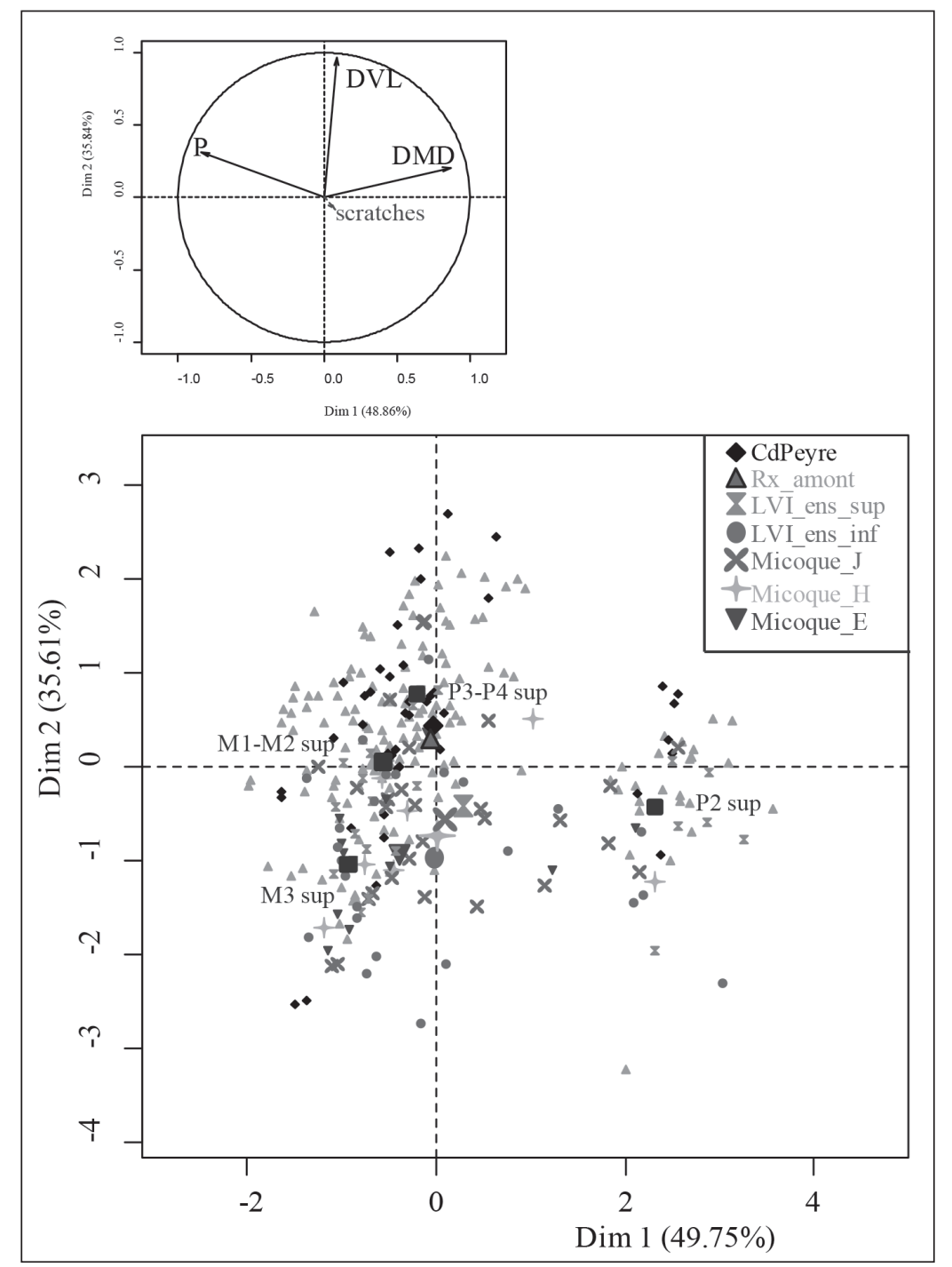

Fig. 3: Principal component analysis of horse upper teeth.

The average of the scratches observed on tooth enamel is shown as illustrative data. The largest icons represent the centroids of the different sites, the squares represent the centroids of the dental rows.

Fig. 3: Analyse en composantes principales sur les dents supérieures de chevaux. La moyenne des rayures observée sur l'émail des dents est indiquée comme une donnée illustrative. Les icones les plus grosses représentent les barycentres des différents sites, les carrés, les barycentres des rangs dentaires.

\begin{tabular}{|c|c|c|c|}
\hline & DMD & DVL & PROTOCONE \\
\hline \multicolumn{4}{|c|}{ Micoque/Lune I-Viel } \\
\hline $\mathrm{p}$-value & 0.65 & 0.99 & 0.99 \\
\hline \multicolumn{4}{|c|}{ Rameaux/CdPeyre } \\
\hline $\mathrm{p}$-value & 0.93 & 0.01 & 0.94 \\
\hline \multicolumn{4}{|c|}{ Rameaux/Micoque } \\
\hline p-value & 0.48 & 0.00 & 0.00 \\
\hline \multicolumn{4}{|c|}{ Rameaux/Lunel-Viel } \\
\hline p-value & 0.96 & 0.00 & 0.00 \\
\hline \multicolumn{4}{|c|}{ CdPeyre/Lunel-Viel } \\
\hline $\mathrm{p}$-value & 0.49 & 0.00 & 0.00 \\
\hline \multicolumn{4}{|c|}{ CdPeyre/Micoque } \\
\hline $\mathrm{p}$-value & 0.03 & 0.00 & 0.00 \\
\hline
\end{tabular}

Tab. 2: Result of the Kruskal-Wallis test on the measurements of horse teeth from La Micoque, Igue des Rameaux, Camps-de-Peyre and Lunel-Viel. $\alpha=\mathbf{0 . 0 5}$.

Tab. 2 : Résultat des tests de Kruskal-Wallis concernant les mesures des dents de chevaux de la Micoque, l'Igue des Rameaux, Camps-de-Peyre et de Lunel-Viel. $\alpha=0,05$. not seem to be linked to the chronological position or the climatic contexts of the studied sites.

\section{4 - FOOD AND HORSE BEHAVIOUR}

\section{1 - DENTAL MESOWEAR}

In total, 162 upper and lower teeth were observed (tab. 3). For all the sites, the results are comparable and all the series provide mesowear scores higher than 4 (fig. 4).

In comparison to reference data on extant ungulates (Mihlbachler et al., 2011), the high values for all the layers/complexes of the studied sites shows that all the horses were preferentially grazers, with food dominated by abrasive plants such as grasses.

\section{2 - DENTAL MICROWEAR}

The average number of scratches and pits is illustrated 


\begin{tabular}{|c|cccccccc|}
\hline Abrasion & Mic_E & Mic_H & Mic_J & CdePeyre LVI_sup & LVI_inf & LVIV & Rx_amont \\
\hline 3 & & 4 & 4 & 2 & 1 & 1 & 1 & 25 \\
\hline 4 & & 1 & 5 & 27 & 6 & 15 & 2 & 61 \\
\hline 5 & 5 & 3 & 9 & 9 & 8 & 3 & 6 & 28 \\
\hline 6 & & & 2 & & 5 & 2 & & 48 \\
\hline total & $\mathbf{5}$ & $\mathbf{8}$ & $\mathbf{2 0}$ & $\mathbf{3 8}$ & $\mathbf{2 0}$ & $\mathbf{2 1}$ & $\mathbf{9}$ & $\mathbf{1 6 2}$ \\
\hline
\end{tabular}

Tab. 3: Number of studied teeth with tooth mesowear scores.

Tab. 3 : Effectif des dents étudiées selon degré de méso-usure dentaire.

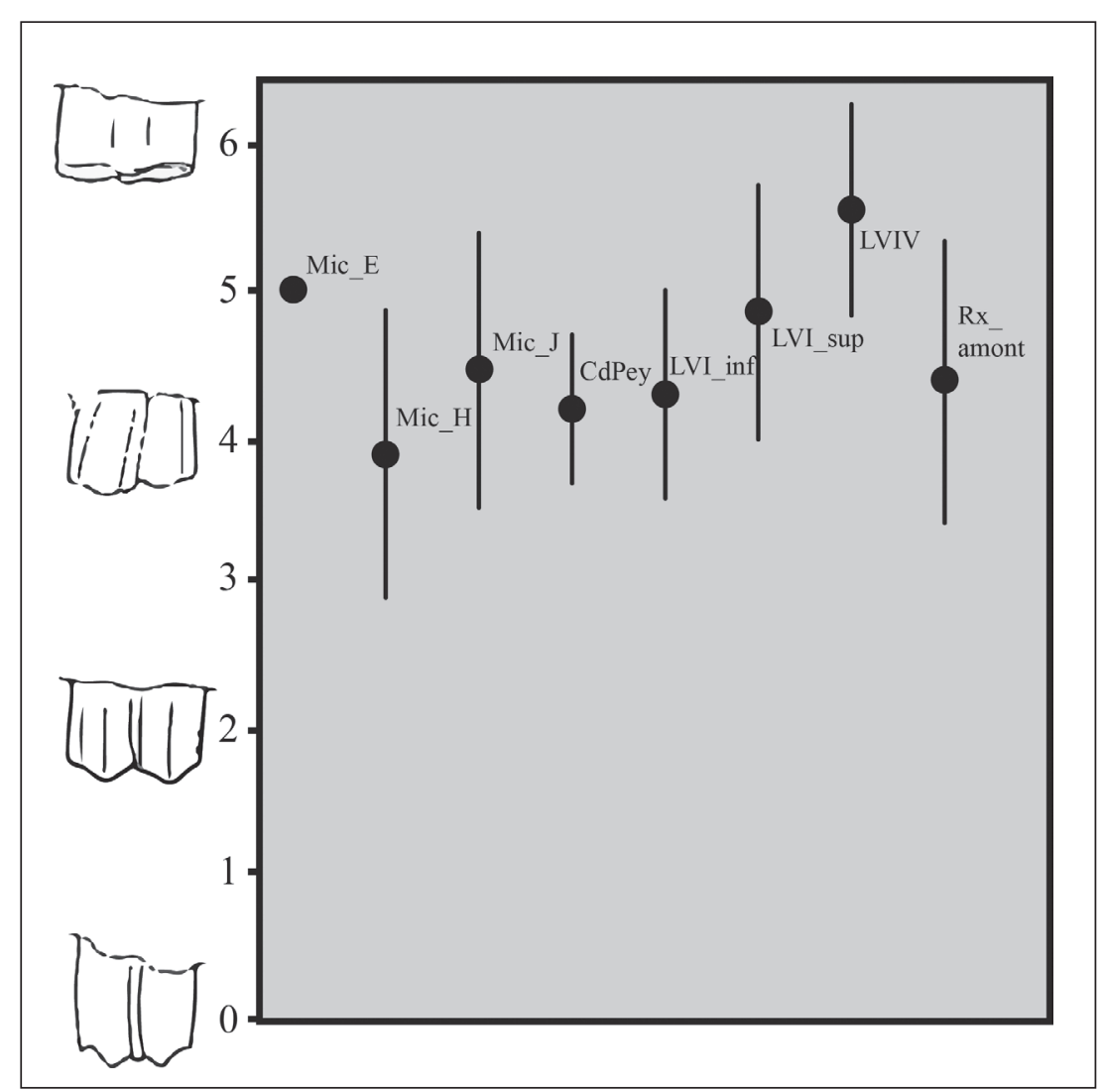

Fig. 4: Mesowear score for the samples from La Micoque, Camps-de-Peyre, Lunel-Viel and Igue des Rameaux sites. Fig. 4: «Mesowear score» des sites de La Micoque, Camps-de-Peyre, Lunel-Viel et de l'Igue des Rameaux.

in figure 5 and summarized in table 4 . The 95\% confidence ellipses correspond to the data established on extant animals (Solounias \& Semprebon, 2002).

The horse upper and lower teeth from Lunel-Viel, La Micoque and Camps-de-Peyre present high numbers of scratches with an average of more than 17 . This indicates the preferential consumption of abrasive plants, such as grass. The horses from Camps-de-Peyre are slightly different to those from Lunel-Viel and La Micoque with higher average number of pits. The abundance of pits on teeth is often correlated to the repeated ingestion of dirt (Hoffman et al., 2015) mixed with food, which must have been the case at Camps-de-Peyre.

At Igue des Rameaux, where deposits were accumulated during a single summer season, (Coumont, 2006), the number of observed scratches is lower and the teeth can be attributed to the browser group. During the last days of their lives, their diet was probably more folivore, oriented towards less abrasive plants such as leaves, buds or tender plants (with low content in phytoliths).

The combination of dental mesowear and microwear methods bring accurate results about the dietary behaviour of Equus mosbachensis ssp. For four of them (La Micoque, Lunel-Viel I and IV and Camps-de-Peyre), the horses ate the same type of abrasive plants, such as grasses, during their last months and days of life. At Camps-de-Peyre, the grasses eaten during their last days of life were particularly gritty. On the other hand, the horses from Igue des Rameaux seem to have had a more variable diet: oriented towards abrasive plants during the last months of their lives, with a more folivore diet during the summer (Coumont, 2006). It is possible that this behaviour reflects a seasonal adaptation. 


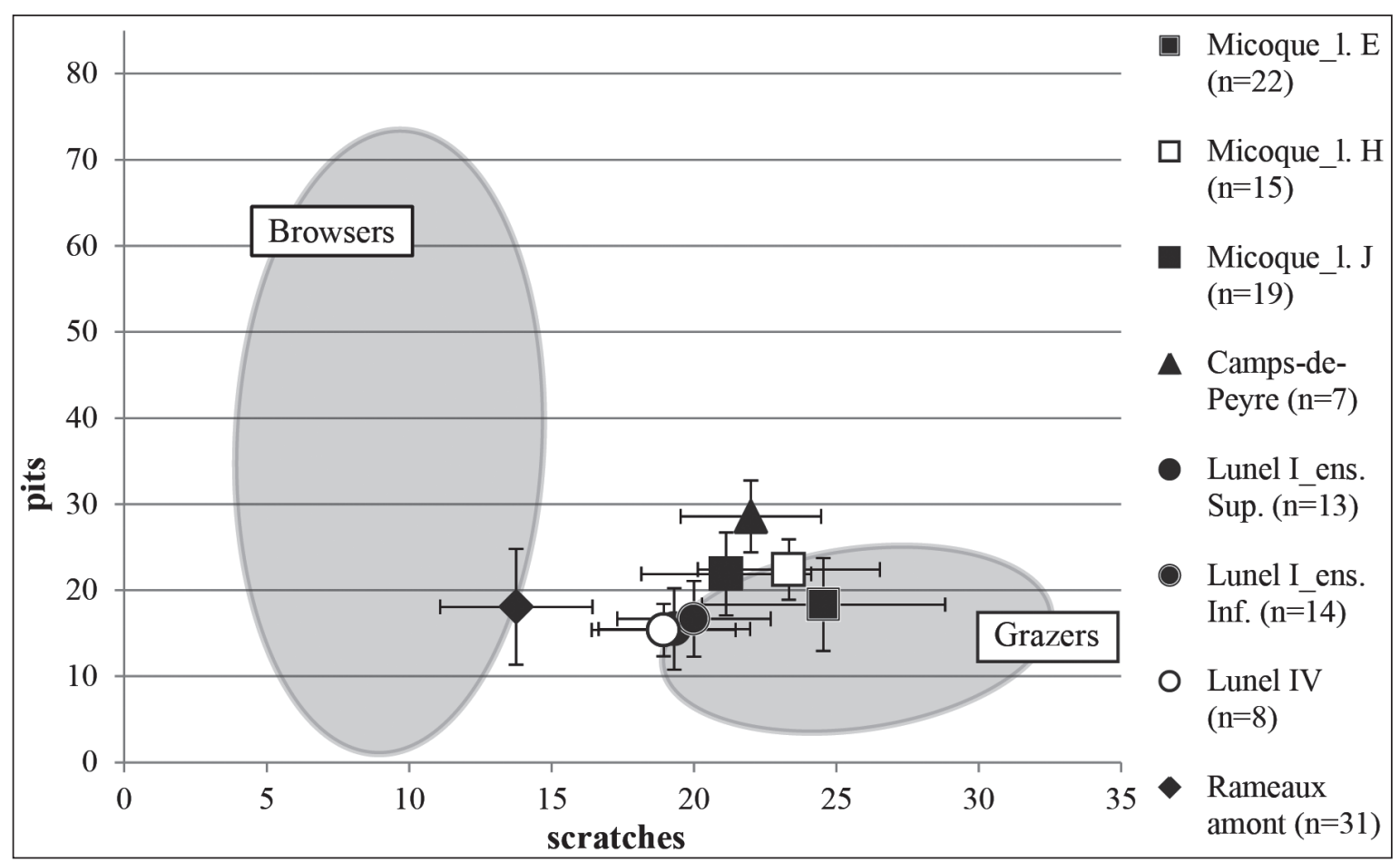

Fig. 5: Average of the numbers of scratches and pits observed on the upper and lower teeth of the horses from Igue des Rameaux (amont complex), Lunel-Viel, Camps-de-Peyre and La Micoque. The grey ellipses (95\% confidence ellipses) represent data based on extant grazers and browsers from Solounias \& Semprebon (2002).

Fig. 5 : Moyennes des nombres de stries et de ponctuations observées sur les dents supérieures et inférieures des chevaux de l'Igue des Rameaux (ensemble amont), Lunel-Viel, Camps-de-Peyre et la Micoque. Les ellipses grises (ellipses de confiance à 95\%) représentent les données établies sur les paisseurs et les brouteurs actuels par Solounias et Semprebon (2002).

\begin{tabular}{|c|ccc|}
\hline Sites \& layers & & mean pit & mean scratches \\
\hline \multirow{3}{*}{ Micoque_I. E } & $\mathrm{n}$ & 22 & 22 \\
& $\mathrm{~m}$ & 18,34 & 24,55 \\
& $\mathrm{~s}$ & 5,41 & 4,27 \\
\hline \multirow{3}{*}{ Micoque_l. H } & $\mathrm{n}$ & 15 & 15 \\
& $\mathrm{~m}$ & 22,4 & 23,33 \\
& $\mathrm{~s}$ & 3,52 & 3,19 \\
\hline \multirow{3}{*}{ Micoque_I. J } & $\mathrm{n}$ & 19 & 19 \\
& $\mathrm{~m}$ & 21,89 & 21,13 \\
& $\mathrm{~s}$ & 4,82 & 2,99 \\
\hline \multirow{3}{*}{ Camps-de-Peyre } & $\mathrm{n}$ & 7 & 7 \\
& $\mathrm{~m}$ & 28,57 & 22 \\
& $\mathrm{~s}$ & 4,17 & 2,47 \\
\hline \multirow{3}{*}{ Lunel I_ens. Sup. } & $\mathrm{n}$ & 13 & 13 \\
& $\mathrm{~m}$ & 15,5 & 19,31 \\
& $\mathrm{~s}$ & 4,72 & 2,66 \\
\hline \multirow{3}{*}{ Lunel I_ens. Inf. } & $\mathrm{n}$ & $\mathrm{1}$ & 14 \\
& $\mathrm{~m}$ & 16,68 & 20 \\
& $\mathrm{~s}$ & 4,39 & 2,7 \\
\hline \multirow{3}{*}{ Lunel IV } & $\mathrm{n}$ & 8 & 8 \\
& $\mathrm{~m}$ & 15,38 & 18,94 \\
& $\mathrm{~s}$ & 3,06 & 2,53 \\
\hline \multirow{3}{*}{ Rameaux amont } & $\mathrm{n}$ & 31 & 31 \\
& $\mathrm{~m}$ & 18,06 & 13,76 \\
& $\mathrm{~s}$ & 6,73 & 2,67 \\
\hline
\end{tabular}

Tab. 4: Averages of the numbers of scratches and pits observed on all the samples and graphically represented in figure 5 .

Tab. 4 : Moyennes des rayures et des ponctuations observées sur l'ensemble de l'échantillon et représentées graphiquement sur la figure 5.

\section{3 - SEASONALITY OF THE ACCUMULATIONS}

The five studied sites can be divided into three groups (fig. 6): at two of the sites, the accumulations are mainly paleontological (Lunel-Viel, Campsde-Peyre), and are placed in group A (accumulation over one season or less), whereas the archaeological accumulation of La Micoque E corresponds to group B (occupation over several contiguous seasons). For layers $\mathrm{H}$ and $\mathrm{J}$ of La Micoque, and Igue des Rameaux, the high probability value $(\mathrm{p}>0.05)$ does not enable us to distinguish whether the accumulation duration is seasonal or longer. Thereby we cannot discuss the observation of Coumont (2006) about the horse accumulation taking place in summer at Igue des Rameaux.

The presence of horses in sites with natural accumulations during a single season of the year can be interpreted in two ways: (1) as seasonal movement of populations (migration?) where the horses would only be present near the sites at certain periods of the year; or (2) as accumulations indicating seasonal variation in site accessibility throughout year.

At La Micoque E, horses were hunted by hominins over a long duration, probably over several contiguous seasons. This is indicated by a single occupation spread over several contiguous seasons, or a palimpsest of occupations over one or several years and several seasons with the same characteristics as group B, and illustrating no seasonal preference for site occupation. 


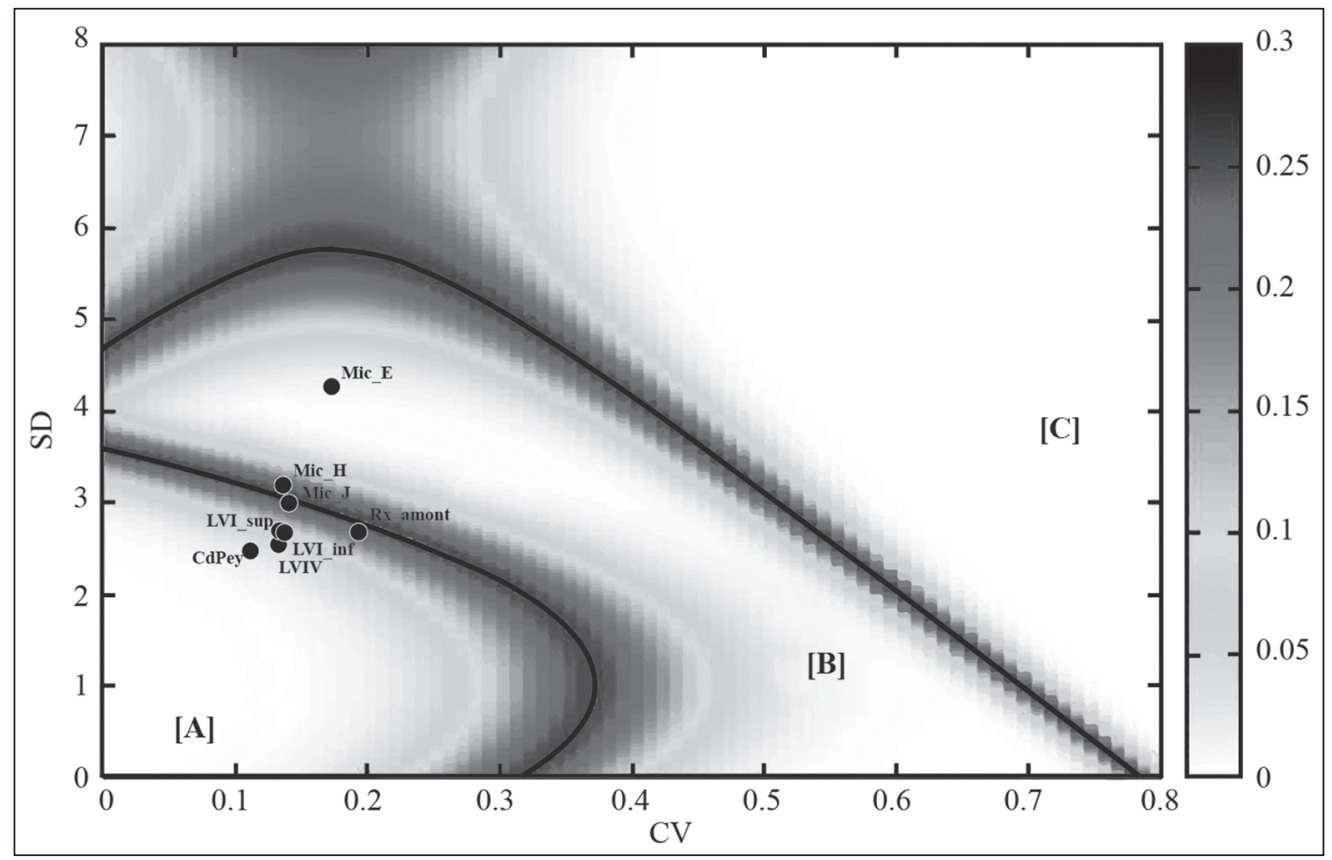

Fig. 6: Distribution of the upper horse teeth from Lunel-Viel, Camps-de-Peyre, La Micoque and Igue des Rameaux (amont) in the limits of the three regions with error probabilities (extant ungulates data and method from Rivals et al., 2015).

Region A: duration of one season or less. Region B: several contiguous seasons. Region C: separated events taking place during non-contiguous seasons. Fig. 6 : Distribution des dents supérieures de chevaux de Lunel-Viel, Camps-de-Peyre, La Micoque et l'Igue des Rameaux (amont) à l'intérieur des limites des trois régions avec les probabilités d'erreur (données des mammifères actuels et méthodes de Rivals et al., 2015). Région A : durée d'une saison ou moins. Région $B$ : plusieurs saisons contigües. Région $C$ : événements séparés prenant place durant des saisons non contiguës.

Thus, at La Micoque E, the occupation seems to have been relatively long or recurrent at different seasons whereas at Lunel-Viel and Camps-de-Peyre, the accumulation of horse remains seems to have occurred during the same season. During the Pleistocene, the composition of the faunal spectra is variable and must be assessed in the light of seasonal factors, which is rarely the case. It is essential to understand the duration and period of site accumulation in order to compare sites on regional or broader scales.

\section{5 - DISCUSSION}

The comparison of dental wear and morphometric indexes enables us to discuss the relationship between anatomy, diet and the environment. Morphology (length of the protocone) and diet (mesowear and microwear) represent different temporal scales (Davis \& Pineda Munoz, 2016): the first is stable all along the lifetime of an individual whereas the second can vary over the course of several days (dental microwear) or several months (dental mesowear). This comparison must thus be considered with caution. Nonetheless, metric data, and particularly the length of the protocone, are regularly used in scientific works to compare body-size and morphology, to describe paleodiets and provide information about environments. During the Pleistocene, we assist to an overall increase in the length of the protocône which seems linked to climatic variations and changes in biotopes (Eisenmann, 1991), but can we really extrapolate global observations from the study of sites and cohorts from limited time periods?

The microwear features observed on the enamel are put in perspective with the length of the protocone using a Spearman statistical correlation test (tab. 5). According to the observations of Solounias \& Sembrebon (2002) on extant fauna, a high number of scratches denotes high consumption rates of grass.

No correlation was established with this test. But none of the previous observations back up this hypothesis either: the horses from la Micoque and Lunel-Viel with short protocones are strictly grazers like the horses from Camps-de-Peyre with longer protocones. The horses from Igue des Rameaux with long protocones are mixed feeders. Our study does not suggest that the length of the protocone is not related to the horse diet on a long temporal scale but suggest that the time latency between morphology and dietary behaviour may be too important to interpret precisely the horse diet and further the local environment during the Pleistocene. Thus, the length of

\begin{tabular}{|ccccc|}
\hline Tooth & P2 & P3/4 & M1/2 & M3 \\
\hline S & 97.173 & 213.93 & 4406.8 & 72.934 \\
\hline Rho & 0.41 & 0.03 & -0.08 & 0.13 \\
\hline P-value & 0.245 & 0.946 & 0.644 & 0.758 \\
\hline \multirow{2}{*}{ result } & $\begin{array}{c}\text { Not } \\
\text { significant }\end{array}$ & $\begin{array}{c}\text { Not } \\
\text { significant }\end{array}$ & $\begin{array}{c}\text { Not } \\
\text { significant }\end{array}$ & $\begin{array}{c}\text { Not } \\
\text { significant }\end{array}$ \\
\hline
\end{tabular}

Tab. 5: Results per tooth of the Spearman correlation test between protocone length and the number of scratches present on the teeth. Tab. 5 : Résultat par dents du test de corrélation de Spearman entre la longueur des protocônes et le nombre de stries présentes sur les dents. 
the protocone does not seem to be a precise proxy for the diet of Pleistocene horses.

Based on this preliminary study, we intended to describe the morphology of the upper teeth in relation to the eco-ethological characteristics of Equus mosbachensis from five French sites dated to the end of Middle Pleistocene (MIS 10 to MIS 9): La Micoque, Camps-dePeyre, Lunel-Viel and Igue des Rameaux (amont). The first two sites were accumulated during cold periods whereas the latter two correspond to a more temperate climate.

The morphometric study enables us to separate these sites into two significantly different groups based on the variable of protocone length:

- Lunel-Viel I and IV and La Micoque: with short protocones;

- Igue des Rameaux (amont) and Camps-de-Peyre: with long protocones.

The ecometric study brought to light two types of dietary behaviour:

- at La Micoque, Lunel-Viel and Camps-de-Peyre: diet oriented towards abrasive plants, such as grass, all year round. In the case of Camps-de-Peyre, the horses ingested some exogenous materiel present on the leaves;

- at Igue des Rameaux (amont): a very abrasive seasonal diet during the months preceding death and softer plants during the summer (Coumont, 2006).

Dental microwear also indicates two different periods concerning the presence of horses in the assemblages:

- Lunel-Viel, Igue des Rameaux (amont) and Campsde-Peyre: in these paleontological cave sites, horses are only present during one season of the year. This can indicate either the presence or the absence of horses around the sites at certain periods of the year or the periodic accessibility and inaccessibility of the sites. These observations show the high variability of the horses and possibly the faunal spectra during the year in the same place and therefore indicate that they must be analyzed with caution;

- La Micoque: in this archaeological site, horses were present during several sequential seasons, pointing to a long hominin occupation of the site or a succession of several short occupations over several consecutive seasons.

This multi-proxy study provides preliminary information concerning the diet of Middle Pleistocene horse Equus mosbachensis, present in Western Europe and beyond. The dietary traits are not linked to morphometry, chronology, climatic context or occupation patterns of the sites. Statistical comparisons between the length of the protocone and the type of diet from our studied sites show non correlation that we cannot consider this measurement as a precise proxy for Pleistocene horse diet and further of the environment it used to live in.

Horses are able to live in various environments and their morphology can change and adapt to different contexts (Cramer, 2002; Van Asperen, 2010). However their dietary habits are broad (Guthrie, 1984; Rivals et al., 2009, Rivals \& Lister, 2016): during the Pleistocene, it has been shown that horses can be either browse-dominated mixed-feeders, like for example at Schöningen in Germany (Rivals et al., 2015) and Deutsch-Altenburg 1 in Austria (Rivals, 2012) or either grazers like at Caune de l'Arago in France (Kaiser \& Franz-Odendaal, 2004). Studies reflect also the various dietary habits it exist among extant equids and show that even E. ferus przewalskii, the last wild horse characterized by a very long protocone is not a grazing specialist but rather a variable grazer and a generalist (Schulz et al., 2011). Our results reflect the same important variability in diet within a single species in a small area that we could not relate with any of the proxies we selected: morphology of the teeth, climate, and duration of the horses' presence around the site through the year. Using the length of the protocone to extrapolate horse diet is not an enough precise tool to catch their varied feeding strategies but this trait can be related at a more global trend in the Equus lineage. The enlargement of our collections for different fossil and climatic contexts are still needed to develop and envision such ecomorpho-relation.

\section{6 - CONCLUSION}

Even for a single species, Equus mosbachensis, the dietary behaviour is quite variable during the Pleistocene. This study confirms the high ecological flexibility of horses and the significant adaptive capacities of this taxon, which are often underestimated (Rivals et al., 2009; Mihlbachler et al., 2011). These observations could also emphasize the large morphometric skeletal heterogeneity and the difficulties involved in studying this species.

Data concerning the rest of the skeleton (lower teeth and post-cranial remains (Uzunidis, $\mathrm{PhD}$ project), should be included in future studies in order to gain a better understanding of these adaptive mechanisms and relations between forms and environment (topography, climate, vegetation,...). The multiplication of combined biometric and ecometric studies could enhance our understanding of the mechanisms underlying specific and subspecific evolutions of mammals during the Pleistocene.

\section{RÉFÉRENCES BIBLIOGRAPHIQUES}

BEAULIEU J.L. (de), ANDRIEU-PONEL V., CHEDDADI R. GUITER F., RAVAZZI C., REILLE M. \& ROSSI S., 2006 - Apport des longues séquences lacustres à la connaissance des variations des climats et des paysages pléistocènes. Palevol, 5 (1-2), 65-72.

BONIFAY M.-F., 1980 - Le Cheval du pléistocène moyen des grottes de Lunel-Viel (Hérault). Equus Mosbachensis palustris. Gallia préhistoire, 23 (2), 233-281.

COUMONT M.P., 2006 - Taphonomie préhistorique: mammifères fossiles en contexte d'avens pièges. Apport pour l'étude des archeofaunes, $\mathrm{PhD}$ thesis, Université d'Aix-Marseille I, Aix-en Provence, $513 \mathrm{p}$.

CRAMER B., 2002 - Morphometrische Untersuchungen an quartären Pferden in Mitteleuropa. PhD, Diss. Geowissenschaftl. Fak. Eberhard-Karls-Univ, $251 \mathrm{p}$. 
DAVIS M. \& PINEDA MUNOZ S., 2016 - The Temporal Scale of Diet and Dietary Proxies. Ecology and Evolution, 6 (6), 1883-97.

EISENMANN V., 1982 - Le cheval et ses proches parents : évolution et phylogénie. $8^{\mathrm{e}}$ journée d'étude équine, C.E.R.E.O.P.A, Paris, 9-26.

EISENMANN V., 1991 - Les chevaux quaternaires européens (Mammalia, Perissodactyla). Taille, typologie, biostratigraphie et taxonomie. Geobios, 24 (6), 747-59.

EISENMANN V., 1998 - Quaternary Horses: Possible Candidates to Domestication. In The Horse: Its Domestication, Diffusion and Role in Past Communities. Proceedings of the XIII International Congress of Prehistoric and Protohistoric Sciences, Forli, Italia, 8-14 September 1996: ABACO Edizioni, 27-36.

EISENMANN V., 2006 - Pliocene and Pleistocene Equids: Palaeontology versus Molecular Biology. In Lutz Christian Maul, Paul P. A. Mazza, \& R. D. Kahlke (eds), Late Neogene and Quaternary Biodiversity and Evolution: Regional Developments and Interregional Correlations. Proceedings volume of the 18th International Senckenberg Conference (VI International Palaeontological Colloquium in Weimar), 25th-20th April 2004: Courier Forschungsinstitut Senckenberg, 71-89.

EISENMANN V. \& DAVID F., 1990 - Les chevaux des niveaux XI et $\mathrm{Xb}$-c de la grotte du renne à Arcy-sur-Cure (Yonne). In Paléolithique Moyen Récent et Paléolithique Supérieur Ancien En Europe. Mémoires du Musée de Préhistoire d'Ile-de-France, Colloque international de Nemours, 9-11 mai 1988, 325-328bis.

FALGUÈRES C., BAHAIN J.-J. \& SALEKI H., 1997 - U-Series and ESR Dating of Teeth from Acheulian and Mousterian Levels at La Micoque (Dordogne, France). Journal of Archaeological Science, 24 (6), 537-545

FORSTEN A., 1993 - Size Decrease in Late Pleistocene-Holocene Caballoid Horses (Genus Equus), Intra-or Interspecific Evolution? A Discussion of Alternatives. Quaternary International, 19, 71-75.

FORSTEN A., 1999 - The horses (genus Equus) from the Middle Pleistocene of Steinheim, Germany. In G Haynes, J Klimowicz, \& J. W. F. Reumer (eds), Mammoths and the mammoth fauna : studies of an extinct ecosystem. DEINSEA, 6, 147-54.

FORTELIUS M. \& SOLOUNIAS N., 2000 - Functional characterization of ungulate molars using the abrasion-attrition wear gradient: a new method for reconstructing paleodiets. American Museum Novitates, 3301, 1-36

FOSSE P., 1996 - La grotte $n^{\circ} 1$ de Lunel-Viel (Hérault, France) : repaire d'hyènes du Pléistocène moyen. Etude taphonomique du matériel osseux. Paléo, 8 (1), 47-79.

GROMOVA V., 1949 - Histoire des chevaux (genre Equus) de l'ancien monde. Première partie : revue et description des formes. Travaux Inst. Paléontol. Acad. Sci. URSS, t. 17, n 1, 373 p., Trad. Pietresson de Saint-Aubin. Annales du Centre d'Études et de Documentation Paléontologiques, 1955, $\mathrm{n}^{\circ} 13$.

GUADELLI J.-L. \& PRAT F., 1995 - Le cheval du gisement pléistocène moyen de Camp-de-Peyre (Sauveterre-la-Lémance, Lot-etGaronne). Paleo, 7 (1), 85-121.

GUTHRIE R. D., 1984 - Mosaics Allelochemicals and Nutrients an Ecological Theory of Late Pleistocene Megafaunal Extinctions. In P. S. Martin \& R. G. Klein (eds), Quaternary Extinctions: A Prehistoric Revolution. Univ. Chicago Press, 259-298.

HOFFMAN J, FRASER D. \& CLEMENTZ M, 2015 - Controlled Feeding Trials with Ungulates: A New Application of in Vivo Dental Molding to Assess the Abrasive Factors of Microwear. Journal of Experimental Biology, 218 (10), 1538-1547.

JANIS C., 1988. - An estimation of tooth volume and hypsodonty indices in ungulate mammals, and the correlation of these factors with dietary preference. In: Russell, D.E., Santoro, J.P., SigogneauRussell, D. (eds.), Teeth Revisited. Presented at the Proceedings of the VIIth international symposium on dental morphology, Mémoires du Muséum National d'Histoire Naturelle, Paris, 367-387.

KAISER T.M. \& FORTELIUS M., 2003 - Differential Mesowear in Occluding Upper and Lower Molars: Opening Mesowear Analysis for Lower Molars and Premolars in Hypsodont Horses. Journal of Morphology, 258 (1), 67-83.

KAISER T. M. \& SOLOUNIAS N., 2003 - Extending the Tooth Mesowear Method to Extinct and Extant Equids, Geodiversitas, 25 (2), 321-345

KAISER T.M. \& FRANZ-ODENDAAL T.A., 2004 - A mixedfeeding Equus species from the Middle Pleistocene of South Africa. Quaternary Research, 62 (3), 316-323.
KÖHLER M., 1993 - Skeleton and habitat of recent and fossil ruminants, geowissenschaftliche Abhandlungen, 25. F. Pfeil, München, $88 \mathrm{p}$.

LANGLOIS A., 2004 - Au sujet du Cheval de La Micoque (Dordogne) et des comportements humains de subsistance au Pléistocène moyen dans le nord-est de l'Aquitaine, $\mathrm{PhD}$ thesis, Université de Bordeaux I, Bordeaux, $383 \mathrm{p}$

LANGLOIS A., 2005 - Le Cheval du gisement Pléistocène moyen de La Micoque (Les Eyzies-de-Tayac, Dordogne) : Equus mosbachensis micoquii nov. ssp. Paleo, 17, 73-110.

MARQUET J.-C., 1993 - Paléoenvironnement et chronologie des sites du domaine atlantique français d'âge Pléistocène moyen et supérieur d'après l'étude des rongeurs. $\mathrm{PhD}$ thesis, Université de Dijon, Dijon, $636 \mathrm{p}$.

MERCERON G, BLONDEL C, BRUNET M., SEN S, SOLOUNIAS N., VIRIOT L. \& HEINTZ E., 2004 - The Late Miocene paleoenvironment of Afghanistan as inferred from dental microwear in artiodactyls. Palaeogeography, Palaeoclimatology, Palaeoeco$\log y, \mathbf{2 0 7}, 143-63$

MIHLBACHLER M.C, RIVALS F., SOLOUNIAS N. \& SEMPREBON G., 2011 - Dietary Change and Evolution of Horses in North America. Science, 331 (6021), 1178-11781.

RIVALS, F., 2012 - Ungulate feeding ecology and middle Pleistocene paleoenvironments at Hundsheim and Deutsch-Altenburg 1 (eastern Austria). Palaeogeography, Palaeoclimatology, Palaeoecology, 317-318, 27-31.

RIVALS F., \& LISTER A.M., 2016 - Dietary Flexibility and Niche Partitioning of Large Herbivores through the Pleistocene of Britain. Quaternary Science Reviews, 146, 116-133.

RIVALS F., SOLOUNIAS N. \& MIHLBACHLER M.C., 2007a - Evidence for geographic variation in the diets of late Pleistocene and early Holocene Bison in North America, and differences from the diets of recent Bison. Quaternary Research, 68 (3), 338-346.

RIVALS F., MIHLBACHLER M.C. \& SOLOUNIAS N., 2007b - Effect of ontogenetic-age distribution in fossil samples on the interpretation of ungulate paleodiets using the mesowear method. Journal of Vertebrate Paleontology, 27 (3), 763-767.

RIVALS F., SCHULZ E. \& KAISER T. M., 2009 - Late and middle Pleistocene ungulates dietary diversity in Western Europe indicate variations of Neanderthal paleoenvironments through time and space. Quaternary Science Reviews, 28 (27-28), 3388-3400.

RIVALS F., JULIEN M.-A., KUITEMS M., VAN KOLFSCHOTEN T., SERANGELI J., DRUCKER D.G., BOCHERENS H. \& CONARD N.J., 2015 - Investigation of equid paleodiet from Schöningen 13 II-4 through dental wear and isotopic analyses: Archaeological implications. Journal of Human Evolution, 89, 129-137.

RIVALS F., PRIGNANO L., SEMPREBON G, \& LOZANO S., 2015 - A tool for determining duration of mortality events in archaeological assemblages using extant ungulate microwear, Scientific Reports, 5 (17330).

ROUZAUD F., SOULIER M., BRUGAL J.-P. \& JAUBERT J., 1990 - L'Igue des Rameaux (Saint-Antonin-Noble-Val, Tarn-etGaronne). Un nouveau gisement du Pléistocène moyen. Premiers résultats. Paleo, 2, 89-106.

SCHULZ E. \& KAISER T.M., 2013 - Historical distribution, habitat requirements and feeding ecology of the genus Equus (Perissodactyla). Mammal Review, 43 (2), 111-123.

SEMPREBON G., GODFREY L. M., SOLOUNIAS N., SUTHERLAND M. R. \& JUNGERS W. L., 2004 - Can Low-Magnification Stereomicroscopy Reveal Diet? Journal of Human Evolution, 47 (3), 115-144.

SOLOUNIAS N. \& SEMPREBON G., 2002 - Advances in the Reconstruction of Ungulate Ecomorphology with Application to Early Fossil Equids. American Museum Novitates, 3366, 1-49.

TEXIER J.P. \& BERTRAN P., 1993 - Nouvelle interprétation paléoenvironnementale et chronostratigraphique du site paléolithique de La Micoque (Dordogne) : implications archéologiques. Comptes-rendus de l'académie des sciences, Paris, 316 (II), 1611-1617.

VAN ASPEREN E.N., 2010 - Ecomorphological Adaptations to Climate and Substrate in Late Middle Pleistocene Caballoid Horses. Palaeogeography, Palaeoclimatology, Palaeoecology, 297 (3-4), 584-96.

VAN ASPEREN E.N., 2013 - Implications of Age Variation and Sexual Dimorphism in Modern Equids for Middle Pleistocene Equid Taxonomy. International Journal of Osteoarchaeology 23 (1), 1-12. 